\title{
Research on the Mode of Civil Engineering Application-oriented Talents Education
}

\author{
Fanghui Li ${ }^{1}$, Yongjiang Zhao ${ }^{1}$, Wenjun Zhao ${ }^{1}$ \\ ${ }^{1}$ School of Architectural Engineering, Heilongjiang University, Harbin, 150080
}

\begin{abstract}
Nowadays, in order to adapt the trend of economic development and meet the needs of enterprises to the applicationoriented talents, society has already put forward new demands to the increasingly integrated and international civil engineering personnel training model. The education and training of high quality talents should be ensured by the high quality teaching mode. This paper proposes the significance of teaching link under the new situation in view of the civil engineering speciality. For providing references and promoting the engineering education development better, while the topic of civil engineering course teaching reform, innovation and practice, curriculum arrangement, construction of teachers contingent, cultivation target and approach are also discussed in this paper
\end{abstract}

Keywords: Civil engineering; education mode; innovation

\section{Introduction}

With the development of our national economy and the trend of global economic integration, the infrastructure construction scale of our country is growing. The development of civil engineering speciality and talents training is playing an important role to the modernization build of our country. Civil engineering discipline has the characteristic of strong practice, application and innovation as a national key discipline. According to the requirements put forward by outstanding engineers education program of our country, a good engineering application talents should have the ability of innovation, have the capability of solving practical engineering problem and adapting the social development. But now civil engineering graduates that trained by us presents a certain distance with social actual requirements of the talents. Under the increasingly fierce competition of the international environment background, how to cultivate outstanding engineers and satisfy the demand of society are the major issues that need universities and educators to research. The old education mode has couldn't adapt the tendency of social economic development, while the innovation, reform, practice and application should be the mainly research content under the new times.

\section{The malpractice of traditional teaching mode}

There are many drawbacks and shortcomings on teaching mode in our colleges now. First of all, few students can express their views or have a interaction link with their teachers. The teachers teach simply and students tend to focus on the examination content, they can get high marks as long as knowing the knowledge of examination. But in 
practical application they don't know how to use and where to use their knowledge that they have learned in the colleges. They also don't know how to consult the information to solve the difficult problems. It leads to the result that the students' knowledge coverage is narrow and timeworn. This condition is also caused by the current university examination system.

Secondly, for the civil engineering curriculum arrangement, most of time is taken up by theory courses but less chance of experiment and practice is provided to students. That leads to the students' theoretical knowledge divorced from the practical application. Once again, the civil engineering industry needs talents with different special skill in different areas. For example, design personnel should have solid theoretical basis knowledge, construction personnel must have rich experience and judgment ability, and management personnel should have a strong organization, leadership and coordination ability. So it has higher requirements to the arrangement of curriculum structure. But now the single education mode cultivates different students with unified way. That can't arouse the students' interest in learning and the subjective initiative, resulting in the students cannot integrate well with social and enterprise.

In addition, the school education neglects the students' application ability and creative consciousness. That causes the student lack practice consciousness and with poor practical ability, which is one of the reasons of graduates' difficulty in employment now. Enterprises need develop and benefit, but the talents who trained by our universities only have theoretical knowledge whereas without the ability to solve practical problems and they cannot adapt the society. It is not only a waste of time to the university education and educational resources, but also a waste to talents.

\section{The reform of engineering education and the innovation of teaching modes under the new situation.}

To perfect our countries' engineering subject teaching system, our universities need to change the education idea and reform the current teaching pattern, guide students to enhance innovation consciousness and application ability in engineering practice. Based on the implementation of excellence engineer training program ideas and requirements of our country, combined with the new economic condition talents training trends, education present situation of various colleges and universities and the malpractice of education methods, put forward the following suggestions.

\subsection{Determine the new era education concept and talent training target}

Sense of education is the core of the education pattern and teaching methods, only with the guide of right education theory can ensure the accurate implementation of educational methods. Only advanced teaching mode can bring up a large number of international standards of engineering application talents. The 'thick foundation, wide calibre' professional character of civil engineering decides that the students should not only study theoretical basis, but also need to widen their scope of knowledge, familiar with the actual engineering design, construction management and other aspects of knowledge. The specific requirements to application-oriented talents of civil engineering are put forward. Engineering applied talents should have the ability to solve the engineering problems, the acute international vision ,the knowledge of the humanities and natural science, strong 
organization ability and communication skills, can be engaged in civil engineering research, design, construction and management and can make a breakthrough in these areas .

\subsection{The construction of teaching and experiment facilities}

Good teaching condition is the hardware guarantee of education. It requires advanced teaching facilities to meet the teaching requirements especially for engineering disciplines. Universities should ensure the engineering investment, strengthen the laboratory construction, introduce advanced experiment and computer equipment, and meet the students to operate experiment, introduce the latest books, journals, industry standards and other information, improve education conditions and provide advantaged environment construction. At the same time, we should establish a nationwide civil engineering practice base and simulate the actual engineering construction site. So as to not only make the students obtain practice training and understand the procedures of construction, but also guarantee the safety of students and avoid risk in the practice process.

\subsection{The arrangement of courses and credit hour structure}

The basic courses of civil engineering settled by colleges and universities mainly include engineering drawing, three major mechanics, building materials, steel structure, soil mechanics and so on. Practice courses mainly include graduation design, production practice, classroom teaching experiment and classroom teaching design. Classroom theory teaching has occupied most weeks but practice teaching only has taken up a few hours. The new situation of the education model calls for us to set up a reasonable practical teaching system. Therefore, we should transfer the focus from theory teaching to practice teaching, reduce the number of compulsory subjects and add elective course content such as project management and economics courses. Improve the credit hour ratio of curriculum design and practice. Specify the compulsory credit hour of science innovation and society practice, encourage the outstanding students in the competition and guide students to improve engineering practice consciousness and application ability.

Additionally, English is the prime language in international communication. So a great deal of professional English knowledge is the essential ability for engineering talents. We should pay attention to improving students' reading and writing ability. While university English curriculum schedule is too dispersive and two class often have an interval of 3 or 5 days. That results in the students' English learning time is incoherent and the effect is not ideal. We can reduce the time of classroom teaching, increase the number of weekly course and shorten the cycle of teaching.

By comparing Civil engineering curriculum arrangement with some developed countries, summing up domestic education inadequacies is that too many courses are set up but practice classes occupy a lower percentage. That leads to our students' engineering quality education should be strengthened and highlights the goal of cultivation level is "talents can be engaged in engineering".

\subsection{Reform the method of examination}

Usually we assess the condition of students' study mainly by written examination. However, the examination mode like that has great disadvantages in teaching. Firstly, knowledge of the written examination is very limited, students only pay attention to the examination content but ignore the other contents when they study, resulting in the 
students' ability to expand the learning knowledge is very weak and with a narrow scope of knowledge. Secondly, the contents of written examination has very little link with engineering practical application and some of the contents is too old to learn. Thirdly, the written examination mode limits the development of students' ability such as innovative thinking.

Therefore, a reasonable assessment system is the important content of teaching reform. Basic knowledge of assessment cannot be ignored but the final score shouldn't only decided by the written examination. We should emphasize the importance of the ability of practical application and not merely command the knowledge point mechanically.

\subsection{Strengthen the construction of teachers' team}

The construction of teachers' team has a great significance to engineering talents training. Engineering application-oriented engineers education mainly emphasize to combine theory with practice. This requires teachers possess rich engineering practical experience, the latest knowledge structure and scientific research production. Colleges should provide opportunities for teachers to continue their study, enable teachers to know the advanced engineering technology and related theory and overcome the condition that young teachers lack experience. At the same time, we should regulate the structure of teaching staff construction according to the teachers' qualifications, titles, scientific research conditions, engineering experience and so on. In this way, universities will play an active role in promoting the students' engineering application ability.

\subsection{Achieve and implement the cooperation mode between colleges and enterprises}

Based on the plan of the cooperation mode between colleges and enterprises which put forward by excellent engineer education program, emphasizing that our students must tamp foundation and face engineering. The cooperation between colleges and enterprises training mode not only accord with the development of modern society, but also provide a chance to make students understand and contact the society, make students perfect the knowledge study in school by social practise and make them found defects of thinking or knowledge store. So that let the students can not only obtain the complete knowledge system and calculation ability but also have practice and experimental spirit, make them improve their comprehensive quality and can quickly adapt to their work and society.

\section{Conclusion}

The development of civil engineering speciality determines our country's modernization degree. Along with the advancement of science and culture, the expansion of infrastructure construction scale and the increasing exchange with international, put forward higher requirements to the civil engineering talents' quality. It requires educators to deepen the education idea, implement scientific education management system and optimize curriculum. Improve the engineering quality and the teaching level of the educators. Sum up experience and turn out high-quality engineering talents with solid theoretical knowledge, ability of skilled operation, ability of solving engineering problems and adapt to the international development trend. Promote civil engineering of our country to be an integrated, internationalization and 
modern discipline and improve influence of our education system in the international. Education mode of civil engineering application-oriented talents requires the explore and joint efforts of all the educators.

\section{Acknowledgements}

This work was supported by National Science Foundation of China (50908077) and Heilongjiang University Funds for Distinguished Young Scientists (JCL201005).

\section{References}

[1] An Xinzheng, Du Ruixue, Yi Cheng, "Evaluation Analysis on Sustainable Development of Civil Engineering Construction,". Information Management, Innovation Management and Industrial Engineering, International Conference on, pp 219-222, 2009.

[2] T. D. Rhoulac, P. Crenshaw, "Preparing Civil Engineering Students to Meet Workplace Writing Expectations,". Frontiers in Education Conference, 36th Annual, pp.3-7, 2006

[3] Yubao Liang, Chuanjiao Pan, Shaotang Liu, " Innovating the Teaching of Engineering Survey Course and Cultivating," Professional Talents of Civil Engineering Information Engineering and Computer Science (ICIECS), 2nd International Conference on, pp. 1-4, 2010.

[4] Oiger K, Koppel T, Laur T, "Educational problems of civil engineering at Tallinn University of Technology,", Information Technology Based Higher Education and Training, Proceedings of the Fifth International Conference on, pp. 434- 436, 2004.

[5] Zhang Rui, Wang Sheng-wu, "The Development of Civil Engineering Virtual Experimental Platform," Computational Intelligence and Software Engineering. International Conference on, pp. 1-4, 2009.

[6] Zhong jun Ma, "The Education Reform of Surveying Practice of Civil Engineering Major in Application-Oriented University Control," Automation and Systems Engineering (CASE), International Conference on, pp.1-3, 2011. 